\title{
Changes in Chinese wood-based exports to the U.S.: Post Lacey Act amendment
}

\author{
by Ziyi Lu' ${ }^{1}$ Indroneil Ganguly², * and Ivan Eastin ${ }^{3}$
}

\begin{abstract}
The recent adoption of timber legality legislation in the U.S. (the Lacey Act 2008 amendment) requiring timber imports be sourced from legally harvested wood could have profound impacts on China's re-exports of manufactured wood products to the U.S. This study examines empirically how Chinese wood manufacturers' sales to the U.S. have changed in response to the Lacey Act. A sample of 225 Chinese wood manufacturers was drawn from two trade shows in Shanghai, China in 2013. The results reveal that Chinese companies' awareness of the Lacey Act has played an important role in their decision to export to the U.S. over the last five years. The companies who are less familiar with the Lacey Act tend to withdraw from the U.S. market and focus on domestic market. Also the smaller Chinese companies were more likely to withdraw from the U.S. market in the aftermath of the Lacey Act as compared to their larger counterparts. Finally, the Chinese companies that have increased their imports of raw materials from the U.S. were found to have increased their sales to the U.S. market over the last five years.
\end{abstract}

Keywords: forest products trade, Lacey Act, Chinese wood manufacturers, company size, sourcing behaviors, Chinese domestic market

\section{RÉSUMÉ}

La récente adoption de la loi sur le bois illégal aux États-Unis (la Loi Lacey amendée en 2008) requérant que les importations de bois doivent provenir de bois récolté légalement pourrait entraîner des effets marquants sur les réexportations chinoises vers les É.-U. de produits du bois manufacturés. Cette étude étudie de façon empirique comment les ventes des manufacturiers de bois de Chine aux É.-U. ont changé suite à lapplication de la Loi Lacey. Un échantillon de 225 manufacturiers de bois de Chine a été constitué à partir de deux foires commerciales tenues à Shanghai en Chine en 2013. Les résultats indiquent que la sensibilisation des entreprises chinoises relativement à la Loi Lacey a joué un rôle déterminant dans leur décision dexporter aux É.-U. au cours des cinq dernières années. Les entreprises qui ne sont pas familières avec la Loi Lacey ont eu tendance à se retirer du marché américain et à se concentrer sur le marché local. De plus, les petites entreprises chinoises ont été plus enclines à se retirer du marché américain à la suite de ladoption de la Loi Lacey que les entreprises de plus grande taille. Finalement, les entreprises chinoises qui ont augmenté leurs importations de matières premières des É.-U. se sont révélées être celles qui ont augmenté leurs ventes sur le marché américain au cours des cinq dernières années.

Mots clés : commerce des produits forestiers, Loi Lacey, manufacturiers de bois de Chine, taille de lentreprise, comportements d’approvisionnement, marché domestique chinois

\section{Introduction}

The U.S. Lacey Act of 1900 is a statute that prohibits trade in wildlife, fish, and plants that have been illegally taken, possessed, transported or sold in the U.S. On May 22, 2008, the U.S. Congress passed an amendment to the Lacey Act banning commerce in illegally sourced plants and their products-including timber and wood products. The newly amended U.S. Lacey Act was the world's first ban on the trade in illegal wood, a precedent in the fight to eliminate the trade of illegally harvested wood and wood products. The Lacey Act acknowledges and supports other countries' efforts to govern their own natural resources and puts in place powerful incentives for companies trading in wood products to do the same (EIA 2009). The Lacey Act is designed to stem the flow of illegally harvested wood and document foreign sources of wood-based products (Armstrong et al. 2010). U.S. importers are required to declare the species, quantity, value, and origin of wood used in their products. Failure to comply with the Lacey Act can result in civil administrative penalties, forfeiture of goods, criminal fines, or imprisonment.

China and the U.S. are the top two largest wood products trading countries, with China's total value of wood products trade (imports and exports combined) surpassing that of the U.S. in 2010. China is also the U.S.'s largest supplier of wooden furniture and flooring imports and is the second-largest wood products trading partner, following Canada, for the U.S. Given the large volume of wood products trade between the two

\footnotetext{
${ }^{1}$ Graduate student, Center for International Trade in Forest Products (CINTRAFOR), School of Environmental and Forest Sciences, Box 352100, University of Washington, Seattle, WA 98195-2100, USA.

${ }^{2}$ Assistant Professor, Center for International Trade in Forest Products (CINTRAFOR), School of Environmental and Forest Sciences, Box 352100, University of Washington, Seattle, WA 98195-2100, USA.

${ }^{3}$ Director and Professor, Center for International Trade in Forest Products (CINTRAFOR), School of Environmental and Forest Sciences, Box 352100, University of Washington, Seattle, WA 98195-2100, USA.

* Corresponding author. E-mail: indro@uw.edu
} 
countries, the Lacey Act will play an important role in the flow of forest products traded between the United States and China. Moreover, China's wood products industry is heavily dependent on imported logs and lumber as the raw material input for the furniture and flooring industry (Ganguly and Eastin 2011). Many Chinese wood product manufacturers import at least some of their wood raw materials from countries where illegal harvesting is problematic (Gregg and Porges 2009). Given this, there are potential risks that wood products manufactured in China might be more likely to be considered to be suspect timber. The Lacey Act has already impacted the forest product trade between China and the U.S. by making it more difficult for Chinese forest products companies to export to the U.S. market (Tao 2009). As a result of the Lacey Act, Chinese companies are concerned that their international competitiveness might be reduced as a result of higher production and export costs. Conversely, some experts suggest that new opportunities might be created for legally harvested U.S. hardwood products in China (Armstrong et al. 2010).

This article explores how Chinese companies' sales have changed in the U.S. market in the aftermath of the implementation of the Lacey Act. The objective of this research was to understand what factors might influence a change in Chinese firms' exports behavior with respect to the U.S. as a result of the Lacey Act. With this in mind, the following research questions are addressed in this paper:

- How has Chinese companies' awareness of the Lacey Act influenced their exports to the U.S. market?

- What role do company size (based on annual sales revenue) and industry type (furniture vs. flooring) play in Chinese companies' decision to export to the U.S. market?

- How has the Lacey Act affected Chinese companies' raw material sourcing behavior (e.g., sourcing region, use of tropical hardwood, and acquisition of chain-ofcustody certification) and how has this influenced their decision to export to the U.S. market?

- How has the Lacey Act influenced the relationship between export markets and the domestic market in Chinese companies' sales orientation?

\section{Survey and Data Collection}

Data for this study were collected using a structured questionnaire administered at two trade shows in Shanghai, China. The first trade show was the DOMOTEX Asia/CHINAFLOOR Show in March of 2013, and the second one was FMC China (Furniture Manufacturing and Supply China) trade show in September of 2013. There were 40000 visitors and 1100 exhibitors in the DOMOTEX Asia/CHINAFLOOR 2013 Show, and 33834 visitors and 790 exhibitors in the FMC China 2013 Show. The Chinese manufacturers and exporters attending these trade shows were the target population for the survey. Visitors and exhibitors attending the trade shows who also matched the target population criterion were surveyed.

These shows were selected for the survey as they are the largest flooring and furniture trade shows in China. The DOMOTEX Asia/CHINAFLOOR is the largest international flooring trade exhibition in the whole Asia-Pacific region (China Exhibition 2013), whereas FMC China is the third-largest furniture show in the world and the leading furniture trade show in China (10Times 2013).

\section{Survey Data}

A total of 225 valid surveys were collected from the two trade shows. A convenient sampling method was used for conducting the surveys. All the exhibitors matching the target population criterion were requested to take the survey. Visitors at the trade show floor were randomly stopped and screened for the survey. The variables relevant for this survey with their corresponding coding details are described in Table 1.

The survey respondents were asked to indicate how their sales had changed following the implementation of the Lacey Act. This variable represents the dependent variable for this research. This variable is categorical in nature and has the following four levels: (i) no sales to U.S. market during the past five years (coded as 0); (ii) sales to U.S. have decreased over the past five years (coded as 1); (iii) sales to the U.S. have remained the same over the past five years (coded as 2); and (iv) sales to the U.S. have increased over the past five years (coded as 3).

In this study the companies' familiarity with the Lacey Act was evaluated at three levels, ranging from an absolute lack of any information to a high degree of familiarity with the Lacey Act. The impact of the Chinese companies' demographic characteristics on their respective strategic decisions on the U.S. market were also explored in this study. The company's size is an important factor that is often taken into account when analyzing a company's strategies (Ganguly et al. 2013). Industry type is another factor that has been frequently analyzed in the forest product marketing research literature (Buehlmann et al. 2010). In this study, the companies are categorized into six size levels based on their annual sales revenue; the two industries within the forest products sector considered in this research are the flooring and the furniture industries.

The Chinese companies' raw material sourcing practices were also investigated as part of this study. The specific questions included (i) the raw material sourcing regions used by the respondent, (ii) the proportion of tropical hardwoods used in the raw material mix, and (iii) the proportion of certified wood included in the raw material mix.

\section{Model Specification and Evaluation}

The dependent variable is measured using rank-ordered discrete characteristics; hence, it can be defined as a discrete ordinal variable (Ishii-Kuntz 1994). Such ordinal responses cannot be modeled using a classical regression approach because the spacing among the rank-ordered categories cannot be assumed to be uniform (Liao 1994). Moreover, since the coding used in the ordinal-level dependent variable is arbitrary $(0,1$, 2 and 3 in this case), the estimated coefficient of the regression model will depend on the coding used (McKelvey and Zavoina 1975). This study employs an ordinal probit modeling approach for estimating the relationship between the ordinal and discrete dependent variable and the independent variables previously described.

The following model specification is used for the study (Long 1997):

$$
\text { [1] } \quad T_{n}^{*}=\beta z_{n}+\varepsilon_{n}
$$

where

$T_{n}^{*}=$ latent measure of the nth firm's sales change in the U.S, over the last five years, 
Table 1. Data descriptions for the model regression

\begin{tabular}{|c|c|c|c|}
\hline & Variable & Codes Used & Descriptions of the Variable \\
\hline $\begin{array}{l}\text { Dependent } \\
\text { variable }\end{array}$ & Sales_Change_US & $\begin{array}{l}\text { in the past five years } \\
0: \text { no sales; } \\
\text { 1: decrease; } \\
\text { 2: remain the same; } \\
\text { 3: increase }\end{array}$ & $\begin{array}{l}\text { Chinese companies' sales change to U.S. market } \\
\text { in the past five years }\end{array}$ \\
\hline \multirow{16}{*}{$\begin{array}{l}\text { Independent } \\
\text { variables }\end{array}$} & Per_Exp_Hardwood & continuous variable $\%$ & percentage of tropical hardwood raw material \\
\hline & Per_Exp_CoC & continuous variable $\%$ & percentage of chain-of-custody certified raw material \\
\hline & Per_Sales_Dom & continuous variable $\%$ & percentage of domestic sales \\
\hline & Industry & 1: flooring industry & Different forest product industries \\
\hline & & 2: furniture industry & \\
\hline & Lacey_Act & $\begin{array}{l}\text { 0: not aware of; } \\
\text { 1: aware but not familiar; } \\
\text { 2: familiar }\end{array}$ & level of familiarity with the Lacey Act \\
\hline & Sales.Rev & 1: Less than $¥ 10000000$ & company sales revenue in 2012 \\
\hline & & 2: $¥ 10000000$ to $¥ 40000000$ & (indicator of the company’s size) \\
\hline & & 3: $¥ 40000001$ to $¥ 70000000$ & \\
\hline & & 4: $¥ 70000001$ to $¥ 100000000$ & \\
\hline & & 5: $¥ 100000000$ to $¥ 200000000$ & \\
\hline & & 6: more than $¥ 200000,000$ & \\
\hline & Source_Change_RUS & \multirow{4}{*}{$\begin{array}{l}\text { in the past five years } \\
0: \text { no sourcing; } \\
\text { 1: decrease; } \\
\text { 2: remain the same; } \\
\text { 3: increase }\end{array}$} & raw material sourcing change from Russia \\
\hline & Source_Change_US & & raw material sourcing change from U.S. \\
\hline & Source_Change_CAN & & raw material sourcing change from Canada \\
\hline & Source_Change_Sea & & raw material sourcing change from Southeast Asia \\
\hline
\end{tabular}

$z_{n}=$ a vector of explanatory variables as has been identified in the model,

$z_{n}=$ a vector of explanatory variables as has been

$\beta=$ a vector of parameters to be estimated, and

$\varepsilon_{n}=$ a vector of the error term (assumed to follow

a standard normal distribution)

The observed and coded discrete sales choice variable, $T_{n}$, is determined from the model as follows:

[2]

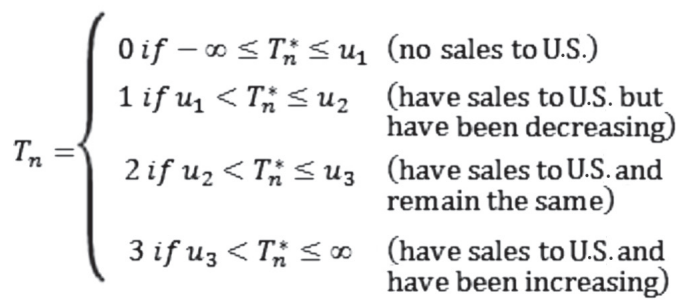

where the $u_{i}^{\prime}$ 's in eq. [2] represent thresholds to be estimated (along with the $\beta s$ ).

In this case of a four-category ordered probit model, $u_{1}$ is set to be 0 and $u_{2}$ and $u_{3}$ need to be estimated.

The probabilities associated with the coded responses of the 4-level ordered probit model in this study are as follows:

$P(0)=P\left(T_{n}=0\right)=P\left(T_{n}^{*} \leq u_{1}\right)=\Phi\left(u_{1}-\beta z_{n}\right)$

$P(1)=P\left(T_{n}=1\right)=P\left(u_{1}<T_{n}^{*} \leq u_{2}\right)=\Phi\left(u_{2}-\beta^{\prime} z_{n}\right)-\Phi\left(u_{1}-\beta^{\prime} z_{n}\right)$

$P(2)=P\left(T_{n}=2\right)=P\left(u_{2}<T_{n}^{*} \leq u_{3}\right)=\Phi\left(u_{3}-\beta^{\prime} z_{n}\right)-\Phi\left(u_{2}-\beta^{\prime} z_{n}\right)$

$P(3)=P\left(T_{n}=3\right)=P\left(u_{3}<T_{n}^{*}\right)=1-\Phi\left(u_{3}-\beta^{\prime} z_{n}\right)$

where $n$ is an individual, $k$ is a response alternative, $\mathrm{P}\left(T_{n}=k\right)$ is the probability that individual $n$ responds in manner $k$, and $\Phi()$ is the standard normal cumulative distribution function. 
After specifying the full set of probabilities and assuming that the sample is identically and independently distributed (iid) on the variables, the parameters of the full model can be estimated consistently and efficiently using the conditional maximum likelihood estimation (MLE) technique, yielding asymptotically normally distributed maximum-likelihood estimates for the stated parameters. Given an iid sample $(i=1,2, \ldots, \mathrm{N})$ and the number of categories $(j=0,1,2,3)$, the log-likelihood function for the stated problem can be written as:

$$
\text { [3] } \quad \iota(\Phi)=\sum_{j=1}^{J} \sum_{i=1}^{n} h_{i j} \ln \left[\operatorname{Pr}\left(y_{i}=j \mid z_{i}, \beta, u_{i}\right)\right]
$$

The open-source statistical software $\mathrm{R}$ has been used for estimating the likelihood model stated in eq.[3]. Model selection and evaluation were undertaken using the two most popular information criteria, Akaike Information Criterion (AIC) and Bayesian Information Criterion (BIC) (Buckland et al. 1997). In this study, the estimated AICc (AIC corrected for sample size) and $\mathrm{BIC}$ values for the proposed models are used to select the best approximating model, and inferences are drawn using the chosen model.

For the purpose of interpretation, the estimated model coefficients are translated into probability values. The effect of each of the significant explanatory variables on the dependent variable are calculated by fixing the values of all other explanatory variables in the model at their respective means, and varying the value of the explanatory variable under consideration. To obtain the bootstrapped estimates, 10000 simulations were run using the variance-covariance matrix and the parameter estimates for the models. The simulation codes were written in R (Adolph 2013). To understand the precision of the estimated probability values, 95\% confidence interval zones are used around the estimated probability curves.

\section{Results and Discussion}

Table 2 shows the model estimates of the ordered probit regression exploring the role of the modeled factors that are likely to influence a change in the Chinese firms' exports behavior to the U.S. in the aftermath of the Lacey Act 2008 amendment. The full model is estimated, including all the variables of interest. A modeling exercise was undertaken to find the most parsimonious model with the best AICc and BIC values. The independent variables "industry" and the "sourcing regions" of
Russia, Canada and Southeast Asia emerged to be statistically insignificant, and were not included in the final model. The three models presented in the table are quite robust with the consistent parameter estimates across the models (Table 2).

To enhance the ease of model interpretability, the model coefficients are translated into probability values and displayed in Fig. 1 and Fig. 2. The results presented in these figures are based on the bootstrapped model. In Fig. 1, the variables included in the final model are displayed along the $\mathrm{y}$-axis. The $\mathrm{x}$-axis displays the probability of the response for each of the categories corresponding to the respective variables on the y-axis. Fig. 2 focuses on the interaction between the Lacey Act awareness variable and the respondents' sales in the domestic market.

The modeling results reveal that the role of the Chinese companies' awareness of the Lacey Act plays a significant role in their export behavior to the U.S. following the implementation of the Lacey Act (Fig. 1). Thus, companies with a higher awareness of the Lacey Act were significantly more likely to have increased their sales to the U.S. over the past five years. The first row of Fig. 1 shows that the respondents who are very familiar with Lacey Act had a 60\% chance of increasing their sales to the U.S. over the last five years, and less than a $10 \%$ chance of reporting that either they do not sell to the U.S. or their sales to the U.S. market have decreased.

The Chinese companies' domestic sales have a negative relationship with their sales to the U.S. market. As can be observed by comparing the third and the sixth rows of Fig. 1, those Chinese companies whose domestic sales percentages are one standard deviation above the mean are $20 \%$ less likely to have increased their sales to U.S. than were those companies who were one standard deviation below the mean. Moreover, these companies that had a higher percentage of sales to the domestic market were $10 \%$ more likely to have no sales to the U.S. market than the group with a lower percentage of sales to the domestic market.

The modeling results reveal that the interaction between "the awareness of the Lacey Act" and the domestic sales percentage is also a significant predictor for the respondents' sales change in the U.S. over the last five years. This aspect of the model is explained in Fig. 2, which represents the probability of the Chinese firms' sales to the U.S. given their awareness level of the Lacey Act. The black line in the figure represents the corresponding probability of the group that is completely unaware of the Lacey

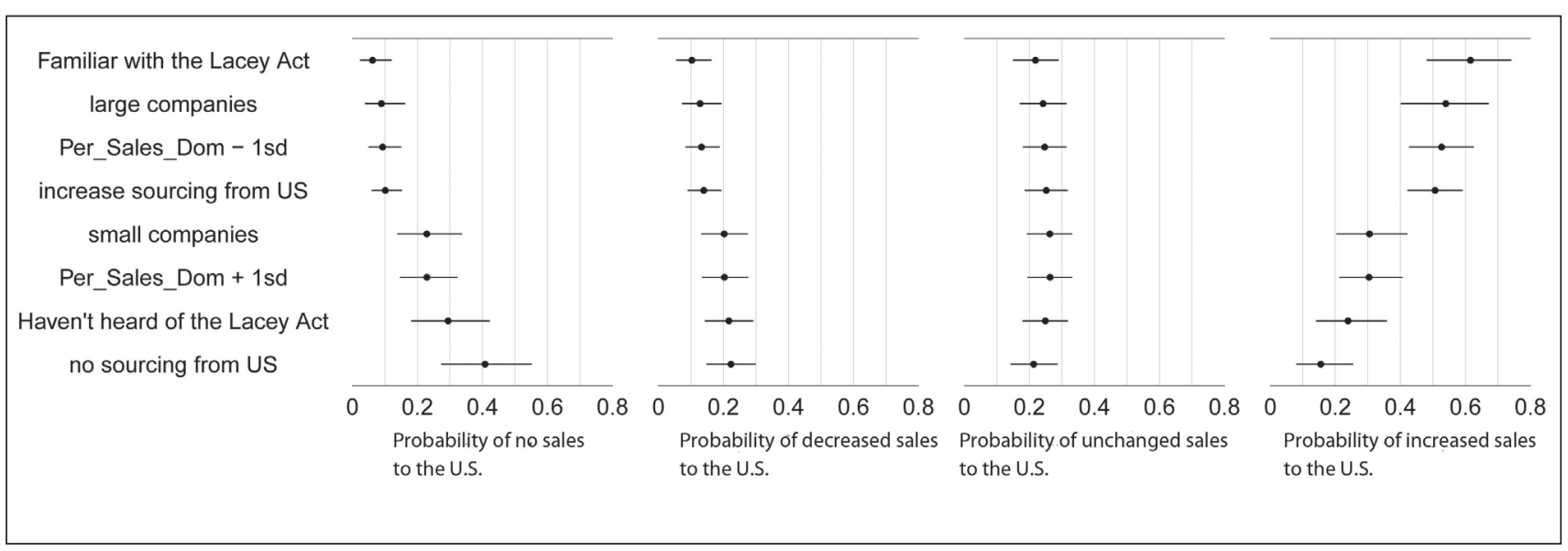

Fig. 1. Rope Ladder representation of the significant model results. 


\begin{tabular}{|c|c|c|c|c|c|c|}
\hline & \multicolumn{2}{|c|}{ Full model } & \multicolumn{2}{|c|}{$\begin{array}{c}\text { Parsimonious M1 w/o } \\
\text { interaction }\end{array}$} & \multicolumn{2}{|c|}{$\begin{array}{l}\text { Parsimonious M2 with } \\
\text { interactions (best fit) }\end{array}$} \\
\hline & Estimates & p-values & Estimates & p-values & Estimates & p-values \\
\hline (intercept) & 0.694 & 0.289 & $0.778^{\star \star}$ & 0.025 & $1.013^{\star}$ & 0.070 \\
\hline Per_Exp_Hardwood & -0.002 & 0.539 & -0.001 & 0.635 & -0.001 & 0.702 \\
\hline Per_Exp_CoC & -0.001 & 0.710 & -0.000 & 0.923 & -0.001 & 0.798 \\
\hline Per_Sales_Dom & $-0.038^{\star * *}$ & 0.000 & $-0.009^{\star * *}$ & 0.000 & $-0.036^{\star * *}$ & 0.000 \\
\hline Lacey_Act & $0.661^{\star *}$ & 0.023 & $0.525^{* * *}$ & 0.000 & $0.613^{\star \star}$ & 0.025 \\
\hline Sales.Rev & $0.112^{*}$ & 0.053 & $0.093^{*}$ & 0.079 & $0.123^{\star \star}$ & 0.025 \\
\hline Industry & -0.203 & 0.308 & & & & \\
\hline Source_Change_rus & 0.081 & 0.266 & & & & \\
\hline Source_Change_us & $0.925^{\star * *}$ & 0.000 & $0.335^{* * *}$ & 0.000 & $0.871^{\star * *}$ & 0.000 \\
\hline Source_Change_can & -0.092 & 0.272 & & & & \\
\hline Source_Change_sea & -0.03 & 0.729 & & & & \\
\hline $\begin{array}{l}\text { Lacey_Act }{ }^{\star} \text { Source_- } \\
\text { Change_US }\end{array}$ & $-0.286^{\star *}$ & 0.020 & & & $-0.264^{\star *}$ & 0.020 \\
\hline $\begin{array}{l}\text { Lacey_Act } \\
{ }^{*} \text { Per_Sales_Dom }\end{array}$ & $0.014^{\star * \star}$ & 0.003 & & & $0.014^{\star *}$ & 0.002 \\
\hline $\mathrm{u}_{2}$ & 1.293 * & 0.051 & $1.317^{\star * *}$ & 0.000 & 0.721 & 1.690 \\
\hline $\mathrm{u}_{3}$ & $1.983 * * *$ & 0.003 & $1.982^{* * *}$ & 0.000 & 0.143 & 0.338 \\
\hline log likelihood & \multicolumn{2}{|c|}{-222.645} & \multicolumn{2}{|c|}{-231.7796} & \multicolumn{2}{|c|}{-224.3419} \\
\hline $\mathrm{AICc}$ & \multicolumn{2}{|c|}{475.8923} & \multicolumn{2}{|c|}{481.7837} & \multicolumn{2}{|c|}{471.0138} \\
\hline $\mathrm{BIC}$ & \multicolumn{2}{|c|}{526.5974} & \multicolumn{2}{|c|}{512.344} & \multicolumn{2}{|c|}{508.31} \\
\hline
\end{tabular}

${ }^{*}$ Values are significant at $p<0.1$.

$* *$ Values are significant at $p<0.05$.

$* * *$ Values are significant at $p<0.01$.

Act, whereas the red line in the figure represents the corresponding probability of the group that has a high level of awareness of the Lacey Act. It can be observed from the steep positive slope of the black line in Fig. 2 that the group that is unfamiliar with the Lacey Act is significantly more likely to have no sales in the U.S. as their domestic sales percentage increases. In contrast, the red line shows that there is no statistically significant relationship between these two variables as the firms become more familiar with the Lacey Act. From the figure it can also be observed that for all levels of domestic sales, the companies that are highly aware of the Lacey Act are significantly less likely to have no sales.

The impact of the Chinese companies' demographic characteristics on their sales to the U.S. was also tested in this paper. It can be observed from Table 2 that the "industry" variable, which explores the difference in sales response by the furniture and flooring manufactures, proved to be insignificant in the regression model. However, company size proved to have a significant positive relationship, which indicates that the larger companies were more likely to increase their exports to the U.S. over the last five years. According to Fig. 1, the large companies were approximately

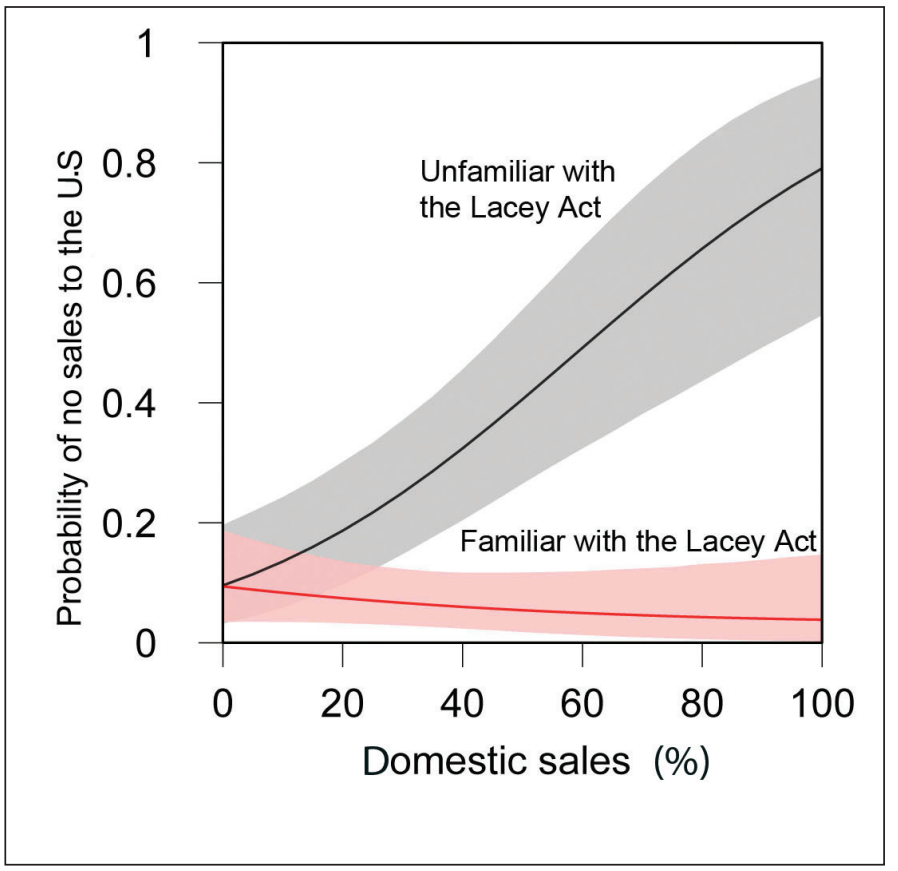

Fig. 2. Role of Lacey Act familiarity on probability of decreasing exports to the U.S. in the last five years. 
$20 \%$ more likely to increase their sales to the U.S. during the last five years relative to the small companies.

With respect to the third research question, whether the Lacey Act has impacted Chinese companies' material sourcing decisions, the model indicates that there is no evidence of any statistically significant relationship between the percentage of the companies' hardwood raw materials or the chain-ofcustody certified raw materials in their supply chain and the companies' sales change behavior in the U.S. market over the last five years. However, a significant positive relationship between a company's sourcing of raw materials from the U.S. and its increased sales to the U.S. was observed. Over the past five years, those Chinese companies that increased their raw material sourcing from the U.S. were also significantly more likely to have increased their sales to the U.S., and vice-versa. From Fig. 1 it can be observed that the companies were approximately $30 \%$ more likely to increase their sales to U.S. if they have increased their sourcing of raw materials from U.S. relative to those companies who did not source raw materials from the U.S.

\section{Conclusions}

This research shows that there is a significant positive relationship between a firm's awareness of the Lacey Act and its change in sales to the U.S. market over the past five years. Based on the nature of the study, a causal relationship between a firm's awareness of the Lacey Act and its sales to the U.S. market cannot be drawn, although it is clear that as a firm's awareness of the Lacey Act increases, its withdrawal from the U.S. market decreases. Moreover, the study also indicates that a lack of awareness of the Lacey Act may contribute to a Chinese company's decision to withdraw from the U.S. market and focus on the less environmentally sensitive domestic Chinese market.

The study also suggests that the Lacey Act may influence Chinese companies' sales strategies in the U.S. market in the same way within both industries (i.e., flooring and furniture). Moreover, over the last five years, the larger companies were able to maintain, and in some cases, even increase, their sales to the U.S. It is evident from the study that the lack of awareness of the Lacey Act has had a greater impact on the smaller companies and may have resulted in their reducing their sales into the U.S. market. It can also be inferred from the study that the Lacey Act has encouraged Chinese companies to increase their import of wood raw materials from the U.S. in order to maintain their exports to the U.S. and more easily demonstrate the legality of the wood used to manufacture their products exported to the U.S., which could enhance the competitiveness of the U.S. forest products industry.

\section{Acknowledgements}

We acknowledge USDA Federal-State Marketing Improvement Program (FSMIP; competitive grant no. 12-25-G-1519) and the USDA McIntire-Stennis Formula Fund for providing financial support to this study. We would also like to thank the American Softwood Export Council for funding the international travel, and American Hardwood Export Council for their help with the data collection.

\section{References}

Armstrong J.P., J. Wang and J. Wu. 2010. An analysis of Appalachian hardwood products in the Chinese market. Wood and Fiber Science 42 (1): 71-80.

Buckland, S.T., K.P. Burnham and N.H. Augustin. 1997. Model selection: an integral part of inference. Biometrics 53(2): 603-618.

Buehlmann, U., O. Espinoza, M. Bumgardner and R. Smith. 2010. Trends in the U.S. Hardwood Lumber Distribution Industry: Changing Products, Customers, and Services. Forest Products Journal 60(6): 547-553.

ChinaExhibition.com. 2013. The 15th Domotex Asia/China Floor 2013 [online]. Available at http://www.chinaexhibition.com/trade_ events/2231-The_15th_Domotex_Asia/China_Floor_2013.html.

Adolph, C. 2013, Maximum Likelihood Methods for the Social Sciences [online]. Available at http://faculty.washington.edu/ cadolph/?page $=21$.

[EIA] Environmental Investigation Agency. 2009. The U.S. Lacey Act: frequently asked questions about the world's first ban on trade in illegal wood. Version 2. Environmental Investigation Agency, Washington, DC. Available at http://issuu.com/eia-global/docs/eia.laceyreport. english $/ 1$ ? $=7348194 / 1879867$.

Ganguly, I., T. Bowers, I. Eastin and R. Cantrell. 2013. Role of Green Building Programs in Enhancing the Usage of Environmentally Certified Wood in the U.S. Residential Construction Industry. International Journal of Construction Education and Research 9(3): 183-202.

Ganguly, I. and I. Eastin. 2011. Economic and Environmental Aspects of China's Wood Products Industry. CINTRAFOR News (Winter Issue): 1, 3-8.

Gregg, R. and A. Porges. 2009. Amendment to the U.S. Lacey Act: Implications for Chinese forest products exporters. Forest trends. Available at http://www.illegal-logging.info/uploads/LaceyActBriefChinaEN.pdf.

Ishii-Kuntz, M. 1994. Ordinal log-linear models. Sage Publications, Thousand Oaks, CA.

Liao, T.F. 1994. Interpreting probability models: logit, probit, and other generalized linear models. Sage Publications, Thousand Oaks, CA.

Long, J.S. 1997. Regression models for categorical and limited dependent variables (Vol. 7). Sage Publications, Thousand Oaks, CA.

McKelvey, R.D. and W. Zavoina. 1975. A statistical model for the analysis of ordinal level dependent variables. Journal of Mathematical Sociology 4(1): 103-120.

Tao, W.B.Z.L.Y. 2009. Influence of Lacey Act on Sino-USA Forest Product Trade and Its Countermeasures. Forestry Economics 1, 019.

10times.com. 2013. Furniture Manufacturing \& Supply China [online]. 10times. Available at http://10times.com/ furniture-manufacturing-supply. 